\title{
Conceptualization of Female Migrants' Experiences across the Lifespan
}

\author{
Mavis Dako-Gyeke, Phd \\ Department of Social Work, University of Ghana \\ Legon, Accra, Ghana, West-Africa
}

\section{Doi:10.5901/ajis.2013.v2n3p259}

\begin{abstract}
Given the fact that migration is a complex phenomenon, it has become a development policy issue in international and national debate circles. It has a relationship with human growth and development across the lifespan because migratory experiences could have positive or negative effects on the well being of migrants. While males and females have migrated over the years, the general perception is that migrants are primarily males. Furthermore, although in recent years more females are migrating independently and as main income-earners, not much attention has been paid to gender-specific experiences of these migrants. Migration research indicates that female migrants are limited in the extent to which they could take advantage of opportunities and are more vulnerable to risks during the migration process. In this regard, this paper examines females' migratory experiences across the lifespan with emphasis on (a) feminization of migration, (b) determinants of female migration and (c) risks associated with female migration flows. Implications are discussed for research, policy and social work practice.
\end{abstract}

Keywords: Development, Females, Gender, Lifespan, Migration, Well-being.

\section{Introduction and Background}

Migration within and across national borders is a global issue that is as old as humankind. The concern with migration streams has dominated migration theory, research and policy (Jolly and Reeves, 2005) because it is a multifaceted phenomenon, which can have both positive and negative effects on countries of origin, as well as countries of destination. As a result, recently, migration is emerging as a development policy issue in international and national debates and discourses. Ghosh (2009) suggests that migration has a complex relationship with human development because while conditions of human development in the home country determine both the need for and the nature of migration, the process itself generates different human development effects on home and host countries.

The impact of migration on women and men depends on many factors, which have gender implications. These include the type of migration, policies and attitudes of the originating and receiving countries, and gender relations within the household (International Organization for Migration, 2005). Since gender influences how development and migration impact each other, gender dimensions of migration are vital to the achievement of the whole range of Millennium Development Goals (MDGs) and not just the gender equality goal (Murison, 2005). It also has implications for development as it can offer new opportunities to improve the lives of men and women and change oppressive gender relations (Jolly and Reeves, 2005).

Although, over the past four decades nearly as many women as men have migrated, ironically, the common perception is that migrants are primarily males. Also, while more women are migrating independently and as main income-earners, not much attention has been paid to the respective gender-specific experiences of males and females. Moreover, women are referred to as servants of globalization because many of them migrate to serve richer families and leave their family caring role to other family members or less privileged women in their countries of origin (Asis, 2003). This could have awful effects on themselves, their families and communities (Omelaniuk, $n$. d.).

Given that males and females show differences in their migratory behaviors and are exposed to different opportunities, risks and challenges, this paper examines how experiences associated with migration, impact on the development and well-being of females across the lifespan. Specifically, the paper discusses: (a) feminization of migration (b) why females migrate and (c) risks that female migrants are exposed to across the lifespan. Although extant literature has explored the causes of migration among females, as well as difficulties they encounter at particular stages of development, this paper goes beyond current literature by examining female migrants' experiences across the lifespan. This is essential because female migrants' experiences are influenced by the causes, dangers and the age at which the 
migration journey is embarked upon. All these have implications for female migrants' development and well-being at the various stages of development. Additionally, given that the dangers female migrants may be exposed to as children or adolescents could negatively harm their development and well-being during later years of life, it is useful to situate the discussion in a lifespan perspective.

\section{Feminization of Migration}

Since the early 1980s, an increasing number of both single and married women have been moving on their own to take up jobs in other countries (Chammartin, n. d). Based on population censuses covering both documented and undocumented migrants, the number of female migrants grew faster than the number of male migrants between 1965 and 1990 in industrialised as well as developing countries (Chammartin, n. d). Globally, the number of female migrants has been large and increasing, both in terms of the sheer number of women involved and of their share of the world's migrant stock (Zlotnik, 2003). For instance, by 2005, 47.4 percent of the 17 million immigrants in Africa were women, up from 42.3 percent in 1960 (Caritas Internationalis, n.d).

Although most African women migrate within the region, they also move to North America, Europe and other places. For example, in migration flows from Cape Verde to Italy, female migration accounts for 85 percent (Caritas Internationalis, n.d). Feminization of migration is a trend that began in the early 1980s (Moreno-Fontes, 2005) and in recent years, the term is commonly used in the public domain by way of research and other reports (United Nations International Research and Training Institute for the Advancement of Women, United Nations INSTRAW, 2007). While it has been argued that feminization of migration is misleading and may result in deliberations on its relevance, by 1960 women already made up nearly half of all international migrants (United Nations INSTRAW, 2007). This number seems not to have changed much during the subsequent four decades (International Labour Organization 2003; Jolly and Reeves, 2005; United Nations INSTRAW, 2007).

On the other hand, feminisation of migration is tangible because it brings to light vital issues such as specific problematic forms of migration and the commercialised migration of women and girls as domestic workers and caregivers that often result in the trafficking of women for labour and sexual exploitation (Caritas Internationalis, n.d). Furthermore, mention can be made of the increased mobility of women in many regions of the world as well as the change in migration patterns, specifically the increasing number of women migrating as breadwinners (Jolly and Reeves, 2005; United Nations INSTRAW, 2007). These are vital developmental issues that need to be addressed because feminisation of migration is similar to two other transformations that affect women's well being and these are feminisation of poverty and feminisation of work (United Nations Population Fund and International Organization for Migration, 2006). In as much as these feminine issues have implications for women's economic development and often discussed in international discourses and debates, they equally have implications for physical, cognitive, psychological and social development of women across the lifespan.

\section{The Lifespan Development Theory and Females Migratory Flows}

The lifespan perspective is appropriate for discussion on female migrants' experiences because it highlights lifetime developmental concerns of both sexes from infancy to old age. According to human development scholars (for example, Berk, 2007; Staudinger and Lindenberger, 2003), the theory emphasises how each period of life has its own developmental challenges and accomplishments, and how adaptive processes are at work at each of the periods of the life span. No age or stage of development is supreme; rather events occurring at each stage have effects on future development. Every stage of development has its own schedule, demands and opportunities that yield some similarities in development among individuals in that stage.

Human development scholars assert that the lifespan paradigm is built on the following four important assumptions. Firstly, human development is lifelong; it does not cease when adulthood is reached, but rather human development begins at conception and ends at death. Secondly, human development is multidimensional or multidirectional because it is affected by a complex combination of biological, cognitive, psychological and social forces. Thirdly, human development is highly plastic for the reason that change is possible at all stages as humans grow and mature. Finally, human development is affected by multiple interacting forces as pathways of change are varied and the developmental domains are not separate but overlapping.

As indicated in Figure 1, life and migration are related because there is no stage of human development that females do not migrate. The lifelong approach is useful for a discussion on females' migratory flows for the reason that 
some experiences are related to age and can have profound effects on future development and well-being. Additionally, migration is influenced by varied factors, including economic, social, cultural practices, biological/medical, geographical, conflict, flight from natural disasters, individual capacities and coping strategies and religious /spiritual (Ghosh, 2009; Jolly and Reeves, 2005; Kwankye et al., 2009). These factors affect the duration of stay and type of migration, that is, residential, internal, international, regular, irregular, forced, voluntary, short-term, long-term, short distance or long distance. Moreover, during the migration process, females encounter different risks, challenges and opportunities and these could have positive or negative effects on their development and well-being.

Figure 1: Migration and Lifespan Framework

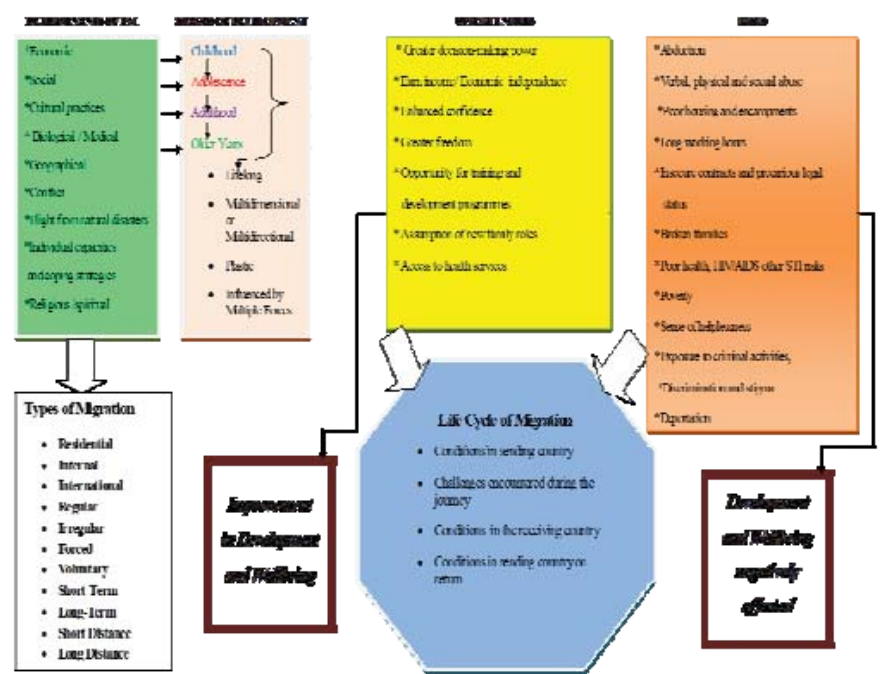

**FM- Female Migration

\section{Determinants of Female Migration}

The causes of female migration may be different from males because females perform different roles in the family, society, and economy (Lauby and Stark, 1988). While the common perception is that most females migrate for marriage or to depend on husbands for economic and social support (Werbner, 1995; Wray and Bartholomew, 2006), there are other reasons as well because both single and married women migrate with or without their families (Ghosh, 2009). Also, even as females of all ages migrate, young women dominate in migration as there is mounting evidence of mothers who have migrated in search of jobs and have left the care of their children with family members who remain at home (Ghosh, 2009).

Different factors cause women to migrate since decisions to migrate are made in response to a mixture of economic, social and political pressures and incentives (Jolly and Reeves, 2005). The factors may play out differently for females depending on their age and could also influence their duration of stay in transit, as well as in the receiving country. Specifically, individuals might migrate due to the desire for a better life, to escape poverty, political persecution, social or family pressures (Jolly and Reeves, 2005) or to flee from conflicts, wars and natural disasters.

While there are a myriad of factors, major extant studies on migration conclude that economic disparities between developing and developed countries continue to be a key determinant of movements from poor (Omelaniuk, n.d.; UNDP, 2005) to developed countries. As women with children need jobs to enable them take care of themselves and their families, they leave their children and other vulnerable family members in the care of their fathers, aunts or grandmothers, migrate and often become employed as childcare providers in receiving countries. Ehrenreich and Hochschild (2003) suggest that a combination of demographic change, growing participation of women in the workforce and reduced social services for child and aged care in many developed countries, has led to a dependency by rich countries on the care offered mainly by females from poor countries.

As remarked by Piper (2005), globally, many women who migrate find work in unskilled occupations as domestic or care workers or in manufacturing and to a lesser extent in agriculture. The few women who work in manufacturing 
companies fill the less-skilled jobs and the migrant skilled women are most often employed by welfare and social professions, such as education, health, social work, which are traditionally female jobs (Jolly and Reeves, 2005; Omelaniuk, n. d.). Employment opportunities that have opened up in the service sectors, such as domestic work, nursing and teaching in Europe, North America and parts of Asia, have become niches for female migrants from poorer regions of the world (Al-Ali, 2004).

Furthermore, female migration is motivated by other non-economic reasons (Geist and McManus, 2012; Omelaniuk, n.d.). It is not always the poorest who migrate because of the costs, challenges and opportunities involved in the process (World Bank, 2005). Some of the non-economic reasons are surveillance by communities and patriarchal traditions that limit opportunity and freedom, quitting bad and abusive marriages, fleeing from domestic violence, desiring equal opportunities, lack of health care facilities, abusive cultural practices (UNFPA and IOM, 2006), moving away from conflict and civil wars, being trafficked, family reunification, government policies on migration (Jolly and Reeves, 2005). Moreover, as gender attributes are usually assigned by cultures, migration choices and constraints of females may differ depending on their socio-cultural origins (Omelaniuk, n.d). Normally, when females are assigned restrictive gender roles in their home countries, by either culture, religion or both, they are likely to migrate in order to escape such situations (Zachariah, Mathew, and Rajan, 2001).

Gender discrimination and violence can also offer the thrust for women to migrate or enable women to be trafficked (Jolly and Reeves, 2005). For example, the preference for male children in India and in Tanzania, force women to migrate when they are excluded from land inheritance (Black, Hilker, and Pooley, 2004). With regard to health, some females migrate to seek health care either for themselves or may accompany sick family members who migrate for health reasons. Moreover, government policies that are related to demographic planning, such as the one child policy in China, has encouraged both voluntary and involuntary migration of women (mostly internal) (IOM, 2005).

\section{Risks Associated with Female Migration Journeys}

Since the migration process is a transforming experience (Awumbila, 2007), it entails both positive and negative experiences, which could bring gains and losses at various stages of development. Even though other factors contribute, the developmental stage or age of female migrants normally influences the extent to which they manage risks or take advantage of opportunities. These risks and opportunities might improve or worsen their development and well being as indicated in Figure 1, because there are variations in the migration experiences among females. The diversity relates to the social, economic and political changes in both home and host locations.

Although both males and females are exposed to opportunities and risks during the migration process, this paper focuses on the dangers female migrants encounter. Compared to males, females are more vulnerable because of their unequal social, economic and political status in society (Brownmiller, 1975; Millet, 1971; Nerenberg, 2002). In this regard, not many female migrants are able to take advantage of available opportunities during transition or in their areas of destination. Jolly and Reeves (2005) concur and suggest that on the migration journey, females may suffer risky and dangerous conditions. These could have harmful effects on their well-being across developmental domains at various stages of development.

In their quest to make a living in their places of destination, female child migrants (below 18 years of age), especially unaccompanied ones who migrate internally or over short distances are exposed to dangers that are basically socio-economic in nature and revolve mainly around living conditions (Kwankye et al., 2007). As indicated in Figure 1, the dangers include poor housing, unsanitary conditions and encampments, low income, living on the streets, sexual harassment from security guards and male colleagues and engaging in difficult work. Others are insecure contracts, being physically and sexually abused, poor health care, illness, sense of helplessness, difficulty finding jobs, being victims of criminal activities, disrespectful treatment, insults from customers (Awumbila, 2007; Jolly and Reeves, 2005; Kwankye et al., 2009; Moreno-Fontes, 2005; Quaicoe, 2005) dropping out from school, being trafficked, among others. These dangers could also be encountered during transit or on return to their originating communities.

The relations between poor living conditions of female migrants and their health cannot be overemphasised. Due to poor sanitary facilities and the fact that female migrants usually buy food from street food vendors, there is the likelihood of getting infections like typhoid, cholera, diarrhoea and other gastro-intestinal diseases (Kwankye et al., 2007), as well as being malnourished. The authors further argue that female migrants may not be able to cook because apart from the ingredients, a lot more is required to prepare their food, such as a place, cooking utensils, fuel for cooking and storage of leftover food. In addition, adolescent and adult female migrants could face challenges related to their sexual and reproductive health. 
In view of the fact that most female urban migrants spend their nights at transport stations, market squares and in kiosks, they are likely to be exposed to reproductive and health risks, such as unprotected sex, sexually transmitted infections (STIS) including HIV and AIDS, engaging in commercial sex (Kwankye et al., 2007), being raped, becoming pregnant and raising their children under difficult circumstances. Additionally, infant and maternal mortality rates are higher among migrant females, particularly teenage mothers due to poor health. In a study on child survival among ruralurban migrants in developing countries, Brockerhoff (1995) found that children of female migrants from rural areas generally have poorer survival chances than other urban children.

Most often, female migrants who travel internationally with illegal documents are likely to be caught by the authorities in their country of origin or destination (Moreno-Fontes, 2005). In such situations, they are likely to be repatriated, sent to jail or homeless shelters with negative consequences for their development and well-being. As noted by Jolly and Reeves (2005), migration can expose females to new vulnerabilities due to precarious legal status, exclusion and isolation. These migrants may become victims of physical and sexual abuse from their hosts and could be treated as slaves where they become properties of these hosts. Often, such female migrants live in isolation with no contact with their families, unable to receive basic amenities like health care and education, engage in difficult work for long hours (for example, working on farms, caring for the sick and the aged) receive low or no wages.

While immigrant women are present among highly skilled workers, they are more often than not visible at the bottom rungs of stratified services, retail and manufacturing sectors (Piper, 2005). The author therefore concludes that indicators of immigrant women's labour include lower participation in labour force, considerable degree of downgrading, low-status occupations and jobs, poor working conditions and low earnings. Most migrant women are often forced to accept subordinate and less secure employment and may therefore feel that their skills are not appreciated or respected (Piper). Generally, women do not have the same labour opportunities abroad and are likely to earn less than men (International Labour Organization, 2004). Female migrants, particularly if they are irregular migrants, can face stigma and discrimination as well as racism at the various stages of the migration cycle. Even before departure, females could be victims of gender-biased procedures and corrupt agents (Jolly and Reeves, 2005; Thiara, 2003; Wray and Bartholomew, 2006).

There are also instances that female migrants with legal documentation are exposed to risks due to language barriers, lack of education and skills or being in abusive relationships. Moreover, many migrant women with high school and even graduate-level education experience a considerable degree of deskilling and disqualification (Jolly and Reeves, 2005; Piper, 2005). Despite the fact that these experiences have negative consequences for female migrants' development and well-being, their voices are not normally heard and consequently not captured in migration research because most of them live in fear and are therefore reluctant to share their experiences.

Whereas females have actively participated in migration for many years, limited information exists on older women's experiences during migration processes (Guruge et. al., 2010; Guruge and Kanthasamy, 2010). Echoing their concern, Wray and Bartholomew (2006) suggest that while an increasing number of older people are international migrants, not much attention has been given to the impact of migration on their health and well-being. It is vital to explore female migration experiences during older years because just like the other stages of development, females and males have different experiences, for example, during retirement migration when most older persons migrate either nationally or internationally to their countries or communities of origin, women represent a greater proportion of these older immigrants.

Given that elder abuse is a global issue (Sherman, Rosenblatt and Antonucci, 2008), it stands to reason that older persons who migrate could be abused either before, during or at their destinations. Guruge et al (2010) point out that older female migrants experience various forms of neglect and abuse and that the primary abusers are family members, such as husbands, children, sons-in-law, daughters-in-law and grandchildren. Some of the abuses older migrant women are exposed to are financial, physical, emotional and sexual abuse along with a range of other forms of threat, control, and neglect (Guruge and Kanthasamy, 2010). In the report on older migrant women's perceptions of and responses to abuse and neglect, Guruge and Kanthasamy indicated that a number of researchers (for example, Beiser, Simich, Rummens, Pandalangat, and Singam, 2006; Guruge, 2007; Hyman et al., 2006; Kanthasamy, 2005) have identified risks, such as social isolation, limited income and financial dependence, language barriers, and intimate partner violence.

Moreover, older migrant women take on more work than they can or prefer to do because of the obligation they feel about assisting their children who are often their sponsors, as well as the social exclusion the migrant families face in destination locations (Beiser et al., 2006; Guruge and Kanthasamy, 2010). Likewise, females who migrate internally or internationally after retirement may be exposed to these dangers on their return to their location of origin. Other dangers that older migrant women faced related to limitations in the accessibility and availability of health and settlement support 
services and unfamiliarity with weather and transportation systems (Guruge and Kanthasamy, 2010). The effects of older women's migration experiences on their well-being cannot be underestimated because they might be dealing with personal issues, such as being widowed, dependent, limitations in activities of daily living due to cognitive, physical or psychological impairment and being in severe pain due to illness or abuse.

In northern Ghana for instance, older women alleged to be witches are often ostracised by their families and communities and forced to migrate to witches camps, such as the Gnani and Kukuo camps, where they live in deplorable and harsh conditions. Given that these older women as well as other women who have migrated for a considerable number of years may be neglected by their family members and communities, they could experience psychosocial challenges, such as depression, isolation, and guilt. As older persons are vulnerable due to structural inequalities and human rights violations which disproportionately affect women globally (Nerenberg, 2002), elderly female migrants are likely to experience psychological, physical and sexual abuse that could affect their development and well-being.

\section{Conclusions and Implications}

Extant literature on migration suggests that about half of global migrants today are females. However, there is scanty data on female migrants' experiences and this has implications for research, policy, and practice. Due to the general perception that migration is predominantly a male phenomenon, there is the need for more research on the differences between the migration experiences of males and females, as well as their interconnections. This is vital because gender roles, relations and inequalities affect who migrates and why, how the decision is made, the impacts on migrants themselves, as well as home and host locations (Jolly and Reeves, 2005).

The fact that migration issues figure prominently in public policy debates and discussions, there is an urgent need to enhance our knowledge and understanding regarding the vulnerability of female migrants. Government immigration policies and programs in both sending and receiving countries should provide protection for women migrants, particularly children and the elderly who are more susceptible during the migration process. Female migrants should be offered spaces to strengthen their agency within male dominated structures that usually offer few opportunities for them (Omelaniuk, n.d). This will help reduce the many personal and structural challenges female migrants face and consequently support their settlement to ensure that they do not become strangers in wonderlands.

Furthermore, since female migration has its specific features, which could be sources of risks, it is suggested that professionals, especially social workers should design and implement developmentally appropriate interventions that are gender-sensitive. For instance, the provision of counseling services should offer female migrants avenues and assistance to disclose abuse, assert their rights and learn how to identify and take advantage of opportunities in their home, transit and destination communities or countries. This is vital because exposure to dangers could result in their self-respect, selfesteem and self-reliance becoming damaged or destroyed, which may affect their individual and community well-being.

In view of the fact that well-being depends on many interrelated factors that operate at various levels, social workers should collaborate with and support other stakeholders, such as policy-makers, community leaders and researchers to create an environment that is conducive for female migrants. When planning their programs, these stakeholders should consider the different aspects of well-being since a deficiency in any domain would affect the overall well-being of female migrants. As unfamiliarity may attract hostility in the community or country of destination of female migrants, more social and settlement services should be made available and accessible to them. This would facilitate their settlement and consequently enhance their development and well-being.

Through advocacy and education, social workers can help society to understand female migration as a developmental and transforming experience but not a problem. This would lessen the destructive perceptions and stereotypes that most people have about female migrants. Emphasising the major aspects of migration across the lifespan will bring to the fore female migrants' own agency in deciding to migrate, as well as possible actions that could be taken to defend their dignity globally. As the risks associated with female migrants' journey are reduced, there would be fewer negative effects of migration on females and their development and well-being would be enhanced. This would enable them to contribute effectively to the development of both their home and host countries.

\section{References}

Al-Ali, N. (2004). The Relationship between migration within and from the Middle East and North-Africa and pro-poor policies. A Report by the Institute of Arab and Islamic Studies. Exeter: University of Exeter for the Department for International Development.

Asis, M. B. (2003). Asian women migrants: Going the distance, but not far enough. Retrieved on May 10, 2012, from http://www.migrationinformation.org/Feature/display.cfm?id=103. 
Awumbila, M. (2007). Internal migration, vulnerability and female porters in Accra. Retrieved on June 02, 2012, from http://paa2007.princeton.edu/download.aspx?submissionld=70865

Berk, L. E. (2007). Development through the lifespan. Boston: Allyn and Bacon.

Beiser, M., Simich, L., Rummens, J., Pandalangat, N., and Singam, A. (2006). A community in distress: Report to the community on results of the Tamil mental health community survey. Unpublished manuscript. Canada: University of Toronto.

Black, R., Hilker, L. M., and Pooley, C. (2004). Migration and pro-poor policy in East Africa. Working Paper C7. Brighton: Development Research Centre on Migration, Globalisation and Poverty.

Brockerhoff, M. (1995). Child survival in big cities: The disadvantages of migrants. Social Science and Medicine, 40(10), 1371-83.

Brownmiller, S. (1975). Against our will: Men, women and rape. New York: Simon and Shuster.

Caritas Internationalis. (n. d). The female face of migration.Retrieved on May 15, 2012, from http://www.caritas.org/includes /pdf/backgroundmigration.pdf .

Chammartin, G. (n. d.). The feminisation of international migration. International Migration Programme: ILO.

Ehrenreich, B., and Hochschild, A. R. (2003). Global woman: nannies, maids and sex workers in the new economy. New York: Henry Holt and Company.

Geist, C. and McManus, P. A. (2012). Different reasons, different results: Implications of migration by gender and family status. Demography, 49, 197-217.

Ghosh. J. (2009). Migration and gender empowerment: Recent trends and emerging issues. United Nations Development Programme Human Development Report. Research Paper. Vol. 04.

Guruge, S. (2007). The influence of gender, racial, social, and economic inequalities on the production of and responses to intimate partner violence in the post-migration context. Unpublished doctoral dissertation. Canada: University of Toronto.

Guruge, S., Kanthasamy, P., Jokarasa, J., Wan, T., Chinichian, M., Shirpak, K. R., Paterson, P., and Sathananthan, S. (2010). Older women speak about abuse and neglect in the post- migration context. Women's Health and Urban Life, 9 (2), pp. 15-41.

Hyman, I., Mason, R., Berman, H., Guruge, S., Manuel, L., Kanagaratnam, P., and Tarcicius, R. (2006). Perceptions of and responses to intimate partner violence among Tamil women in Toronto. Canadian Woman Studies, 25(1 and 2), 145-150.

Guruge, S., and Kanthasamy, P. (2010). Older women's perceptions of and responses to abuse and neglect in the post-migration context. Retrieved on May 06, 2012, from http://www.wellesleyinstitute.com/wp_content/uploads/2010/04/Olderwomens perceptionsfinalreport.pdf .

International Labour Organization (ILO). (2003). Preventing discrimination, exploitation and abuse of women migrant workers: An information guide. Geneva: International Labour Organization.

International Labour Organization (ILO). (2004a). Towards a fair deal for migrant workers in the global economy, Report VI. (Geneva). Retrieved on February15, 2012, from http://www.ilo.org/public/english/standards/relm/ilc/ilc92/pdf/rep-vi.pdf.

International Organization for Migration. (2005). World migration report 2005: Costs and benefits of international migration. Geneva: IOM. Retrieved on May 03, 2012, from http://www.iom.int/jahia/Jahia/cache/offonce/pid/1674?entryld=932.

Jolly, S., and Reeves, H. (2005). Gender and migration: Overview report. Brighton: Institute of Development Studies.

Kanthasamy, P. (2005). Violence against women. Toronto: Apex Creations.

Kwankye, S. O., Anarfi, J. K., Tagoe, C. A., and Castaldo, A. (2007). Coping strategies of independent child migrants from northern Ghana to southern cities. Brighton: Development Research Centre on Migration, Globalisation and Poverty.

Kwankye, S. O., Anarfi, J. K., Tagoe, C. A., and Castaldo, A. (2009). Independent North-South child migration in Ghana: The decision making process. Brighton: Development Research Centre on Migration, Globalisation and Poverty.

Lauby, J., and Stark, O. (1988). Individual migration as a family strategy: Young women in the Philippines. Population Studies, 42(3), 473-486.

Millet, K. (1971). Sexual politics. New York: Avon.

Moreno-Fontes, G. (2005). Domestic workers: Little protection for the underpaid. Washington DC: Migration Policy Institute. Retrieved on May 02, 2012, from http://www.migrationinformation.org/feature/display.cfm?ID=300,

Murison, S. (2005). Evaluation of DFID development assistance: Gender equality and women's empowerment: Phase II thematic evaluation: Migration and development. Working Paper 13. London: Department for International Development.

Nerenberg, L. (2002). A feminist perspective on gender and elder abuse: A review of the literature. National Committee for the Prevention of Elder Abuse. Retrieved on June 01, 2012, from http://www.ncea.aoa.gov/ncearoot/main_site/pdf/publication /finalgenderissuesinelderabu se030924.pdf

Omelaniuk, I. (n. d.). Gender, poverty reduction and migration. World Bank. Retrieved on May 02, 2012, from http://siteresources.worldbank.org/extaboutus/Resources/Gender.pdf.

Piper, N. (2005). Gender and migration: A paper prepared for the policy analysis and research programme of the global commission on international migration. Retrieved on April, 20, 2012, from http://www.iom.int/jahia/webdav/site/myjahiasite/shared/shared/ mainsite/policy_and_research/gcim/tp/TP10.pdf

Quaicoe, R. (2005, 26 May). Woes of the kayayoo. The Daily Graphic. Accra: Ghana.

Staudinger, U. M., and Lindenberger, U. (2003). Understanding human development: Dialogues with lifespan psychology.The Netherlands: Kluwer Academic Publishers.

Sherman, C. W., Rosenblatt, D. E., and Antonucci, T. C. (2008). Elder abuse and mistreatment: A life span and cultural context. Indian Journal of Gerontology, 22, 319-339.

Thiara, R. K. (2003). South Asian women and collective action in Britain. In: J. Andall (Ed.), Gender and ethnicity in contemporary 
Europe. Oxford: Berg.

United Nations International Research and Training Institute for the Advancement of Women. (2007). Feminization of migration: Gender, remittances and development. Working Paper No. 1. Retrieved on April, 05, 2012, from http://www.renateeurope.net/downloads/Documents/Feminization_of_Migration-instraw2007.pdf

United Nations Population Fund and International Organization for Migration. (2006). Female migrants: Bridging the gaps throughout the life cycle. Retrieved on March, 05, 2012, from http://www.unfpa.org/webdav/site/global/shared/documents/publications /2006/bridginggap.pdf

United Nations Development Programme. (2005). 2005 Human Development Report. New York.

Werbner, P. (1995). From commodities to gifts: Pakistani migrant workers in Manchester. In: A. Rogers and S. Vertovec (Eds.) The urban context: Ethnicity, social networks and situational analysis. Oxford: Berg.

World Bank. (2005). Global economic prospects 2006. Washington, D.C.

Wray, S., and Bartholomew, M. L. (2006). Older African Caribbean women: The influence of migration on experiences of health and well-being in later life. Research Policy and Planning, 24 (2), 103-119.

Zachariah, K. C, Mathew, E. T., and Rajan, S. I. (2001). Social, economic and demographic consequences of migration on Kerala. International Migration, 39 (2), 43-71.

Zlonik, H. (2003). The global dimensions of female migration. Retrieved on February 12, 2012, from http://www.migrationinformation.org/Feature/display.cfm?ID=109. 